\title{
O CONCEITO DO BELO EM AGOSTINHO DE HIPONA
}

\author{
The Concept of Beauty in Augustine of Hippo
}

Rogério Miranda de Almeida ${ }^{1}$

\begin{abstract}
RESUMO: Estas reflexões têm como principal objetivo mostrar como a concepção do belo em Agostinho de Hipona é tributária da tradição platônico-aristotélica e das Escrituras. No que tange à primeira influência, a ênfase é colocada nas noções de simetria, de proporção, de forma, de unidade e, portanto, de belo. No que diz respeito às Escrituras, Agostinho considera em primeiro lugar o papel da criação e a ação de Deus no universo como o Ser a partir do qual todas as coisas se mantêm harmônica e proporcionalmente vinculadas entre si. Neste universo, ao pôr o acento sobre o homem como a imagem e semelhança de Deus, o teólogo explora igualmente o conceito de participação, que também remete a Platão e às Escrituras. O texto termina apontando para o paradoxo, tipicamente estoico, do apesar de, isto é, apesar do mal, existe o bem, apesar do feio e do desgracioso, existe o belo.
\end{abstract}

PALAVRAS-CHAVE: Agostinho de Hipona; Platão; Unidade; Belo; Participação.

ABSTRACT: These reflections aim at showing how de concept of beauty in Augustine of Hippo is influenced by the Platonic-Aristotelian tradition as well as by the Scriptures. Regarding the former, the emphasis is placed upon the notions of symmetry, proportion, form, unity and, therefore, beauty. Concerning the Scriptures, Augustine considers first of all the role of creation and the action of God in the universe as the Being out of which everything is mutually connected in proportion and unity. In such a universe, as Augustine underscores the role of man as the image and resemblance of God, he explores as well the concept of participation, which also goes back to Plato and to the Scriptures. This text ends pointing out to the typically Stoic paradox of in spite $o f$. Thus, in spite of evil, there is good, in spite of ugliness and disgracefulness, there is beauty.

KEYWORDS: Augustine of Hippo; Plato; Unity; Beauty; Participation.

No Livro IV das Confissões, Agostinho faz referência àquele que, muito provavelmente, teria sido o seu primeiro livro, De pulchro et apto, ou seja, o belo e o conveniente, ou o harmonioso. Infelizmente, este escrito se perdeu, do qual o autor,

\footnotetext{
${ }^{1}$ Doutor em filosofia pela Universidade de Metz e em teologia pela Universidade de Estrasburgo, leciona filosofia no programa de pós-graduação da Pontifícia Universidade Católica do Paraná (PUCPR), filosofia na Faculdade São Basílio Magno (FASBAM) e teologia sistemática no Claretiano - Centro Universitário. E-mail: r.mirandaalmeida@gmail.com
} 
sintomaticamente, diz não mais se lembrar se se tratava de uma obra composta de dois ou três livros. ${ }^{2}$ Além deste tratado perdido, Agostinho não parece ter desenvolvido, de maneira sistemática, um estudo específico sobre o belo e a arte. Há, porém, alusões, referências e considerações sobre a arte e o belo em obras tais como: Sobre a música, $A$ verdadeira religião, A natureza do bem, O livre-arbitrio, As Confissões, e nas epístolas.

$\mathrm{Na}$ verdade, o bem e o belo são praticamente sinônimos sob a pena do autor das Confissões, de sorte que, quando ele define o bem, o mais das vezes ele o reenvia a tudo aquilo que possui medida (modus), forma (species) e proporção (ordo). Deus, no entanto, pondera o teólogo, está acima de toda medida, de toda forma e de toda ordem que pertencem à esfera da criação. ${ }^{3}$ Ora, mesmo nas escassas referências que, na passagem acima citada das Confissões, ele faz ao De pulchro et apto, Agostinho deixa entrever a sua concepção básica do belo que se encontra nas outras obras. Com efeito, ao se perguntar pela essência do belo, da beleza e pelo que, finalmente, nos atrai nos objetos do nosso amor e deles nos aproxima, o próprio Agostinho nos responde: "É a conveniência (decus) e a forma (species), pois se delas fossem privados, não nos atrairiam de modo algum". ${ }^{4}$ Note-se, de resto, que o termo latino "decus" significa não somente conveniência, mas também - e justamente por isso - ornamento, beleza, decoro, dignidade, honra e nobreza.

Já se pode, pois, adivinhar que Agostinho é tributário de três concepções fundamentais do belo e, consequentemente, da manifestação do belo na obra de arte: $1^{\circ}$ ) A primeira diz respeito à teoria platônica do belo como manifestação do bem; $2^{\circ}$ ) a segunda reenvia à doutrina platônico-aristotélica da simetria, da ordem e da harmonia; $3^{\circ}$ ) a terceira concepção, enfim, ele a encontra nas Escrituras e, mais particularmente, na obra da criação, tal como a descreve o primeiro capítulo do Gênesis.

Convém, porém, observar que Agostinho não foi diretamente influenciado pelas doutrinas de Platão, na medida em que o conhecimento que delas recebeu lhe foi transmitido pelo neoplatonismo e pelas referências, as alusões e os comentários que Cícero desenvolvera em torno de Platão e de sua Academia. De Plotino e de seu discípulo, Porfírio, Agostinho leu o que havia sido até então traduzido. Pois, entre os escritores latinos dos quatro primeiros séculos da era cristã, eram escassas as traduções diretas que circulavam a partir de Platão e de Aristóteles. Quanto ao primeiro, havia uma versão

\footnotetext{
${ }^{2}$ Cf. AgOStinho DE HIPONA. Le Confessioni. Torino: Einaudi, 2002, IV, 13, 20.

${ }^{3}$ Cf. La natura del bene. Milano: Rusconi, 1995, Parte prima, 3.

${ }^{4}$ Le Confessioni, IV, 13, 20.
} 
fragmentária que Cícero fizera do Timeu e outra, conquanto mais completa, que fora realizada pelo pensador Calcídio e enriquecida de um comentário inspirado noutro comentário de Posidônio. Havia também traduções de extratos de diálogos, tais como o Mênon, o Fédon e, mais fragmentariamente ainda, da República. Devem-se ainda mencionar as "variações filosóficas" desenvolvidas pelo escritor africano da Numídia, Macróbio (final do séc. IV - início do séc. V), as quais, versando sobre temas platônicos e neoplatônicos, são na verdade um comentário ao Sonho de Cipião, de Cícero. Macróbio escreveu ainda as Saturnais, que é uma compilação dos conhecimentos de sua época.

Feitas, pois, essas ressalvas e as considerações em torno das influências que recebera Agostinho, vejamos em primeiro lugar em que consiste a sua concepção do belo a partir das noções de proporção e de harmonia que se verificam entre o modelo e a imagem que tenta imitá-lo, dele assemelhar-se ou dele participar.

\section{Do modelo e da imagem}

Dentre a diversidade de significados e de nuanças que ressalta da concepção básica de Platão relativamente aos modelos, poder-se-ia sucintamente descrever o modelo como

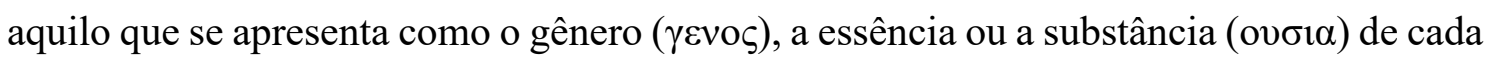
coisa em particular. ${ }^{5}$ Ele pode também exprimir-se como a forma, a espécie ( $\left.\varepsilon 1 \delta \circ \varsigma\right)$ ou, numa palavra, a unidade visível na multiplicidade dos objetos deste mundo. ${ }^{6}$ Neste sentido, é lícito igualmente afirmar que as ideias $(\varepsilon 1 \delta \eta)$ se manifestam na natureza como modelos ou paradigmas $(\pi \alpha \rho \alpha \delta \varepsilon 1 \gamma \mu \alpha \tau \alpha)$ dignos de serem imitados, seguidos ou participados. ${ }^{7}$ Efetivamente, no Timeu, os paradigmas constituem o mundo dos seres eternos, inteligíveis e sempre idênticos a si mesmos, dos quais este mundo sensível - que foi gerado e fabricado pelo Demiurgo - é uma reprodução, ou uma imagem. ${ }^{8}$ Mas o que é uma imagem na perspectiva de Platão?

O filósofo se serve principalmente de dois substantivos para significar a imagem. Um deles é o $\varepsilon 1 \delta \omega \lambda \mathrm{ov}$, do verbo $\varepsilon 1 \delta \omega$ : ver, olhar, observar e, por extensão, representar, fantasiar, imaginar. O outro substantivo é o $\varepsilon ı \kappa \omega v$, do verbo $\varepsilon ı \kappa \omega$ : ser semelhante a, parecer-se com, ter o aspecto de. Ora, além de imagem e figura, o $\varepsilon \imath \delta \omega \lambda o v$ quer dizer:

\footnotetext{
${ }^{5}$ Cf. PLATÃO. Fédon, 65d-e; Parmênides, 135a-b. Todas as citações que faço de Platão são tiradas de: Plato in Twelve Volumes. Cambridge: Harvard University Press, 1977.

${ }^{6} \mathrm{Cf}$. Parmênides, 132a.

${ }^{7}$ Cf. ibid., 132d.

${ }^{8}$ Cf. Timeu, 29a-b; 48e.
} 
fantasma, simulacro, retrato; donde possuir ele também o significado de coisa imitada, falsificada, ou desprovida de status ontológico. Quanto ao $\varepsilon 1 \kappa \omega v$, além de imagem e retrato, ele significa: estátua, quadro e ícone. Ambos os substantivos estão também relacionados ao termo $\mu \mu \eta \sigma ı \varsigma$ (imitação, representação por meio de imagem visual ou auditiva), que, por sua vez, reenvia ao verbo $\mu \mu \varepsilon$ « $\mu \alpha$ : imitar ou ser imitado. Assim, a arte oratória é uma imitação, isto é, um $\varepsilon 1 \delta \omega \lambda o v$ da política, enquanto que o logos escrito se apresenta como um $\varepsilon 1 \delta \omega \lambda$ ov do verdadeiro $\log o s .{ }^{9}$ Consequentemente, o $\varepsilon 1 \delta \omega \lambda o v$ se revela como uma espécie de fantasma, de substituto, ou, mais exatamente, de sombra indefinida vis-à-vis do modelo. É neste sentido que, no Fédon, Platão descreve as almas que deambulam pelos túmulos como $\varepsilon 1 \delta \omega \lambda \alpha .{ }^{10} \mathrm{Na}$ República, são denominadas $\varepsilon 1 \delta \omega \lambda \alpha$ as imagens que o prisioneiro - trânsfuga da caverna - vê refletidas na superfície da água. ${ }^{11}$

Ora, o próprio $\varepsilon 1 \delta \omega \lambda o v$ é ambíguo na medida em que, conquanto se manifeste como uma contrafação, ele não deixa menos de se reportar ao modelo que, bem ou mal, ele tende a imitar. Certo, no que tange especificamente ao $\varepsilon 1 \kappa \omega v$, e embora ele também se caracterize pela imitação, este conceito apresenta a vantagem de fazer ressaltar a noção de semelhança, de cópia, ou do verdadeiro aspecto da realidade que representa, ou tenta representar. Todavia, não é por acaso que - talvez para fazer sobressair ainda mais esta ambiguidade - Platão estabelece, numa mesma passagem, uma relação entre o $\varepsilon 1 \delta \omega \lambda o v$ e o $\varepsilon \kappa \omega v$. É o que verificamos, por exemplo, no diálogo que se desenrola entre Teeteto e o Estrangeiro, no Sofista. Com efeito, afirma Teeteto, sob a forma de interrogação: "O que é uma imagem ( $\varepsilon 1 \delta \omega \lambda \mathrm{ov})$ senão um outro objeto do mesmo gênero feito à semelhança daquele que é verdadeiro?"12 Sobre esta definição, o Estrangeiro lança a questão de saber se esta outra coisa semelhante é ela também verdadeira, ou em relação a que Teeteto afirma que ela é semelhante. Ora, retruca Teeteto: ela não é de forma alguma verdadeira,

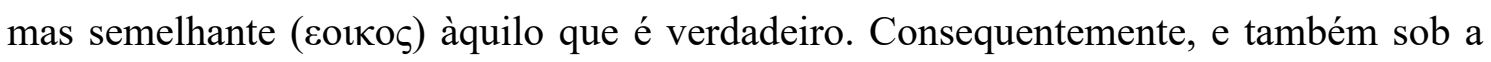
forma de interrogação, o Estrangeiro assevera que é verdadeiro aquilo que realmente é, ou existe. A esta conclusão, Teeteto dá o seu mais pronto assentimento. Sem embargo, rebate o Estrangeiro: "E então, o que não é verdadeiro é o contrário daquilo que é verdadeiro?"13 A esta pergunta, Teeteto aquiesce sem hesitar. E é neste ponto que o Estrangeiro começa a aguçar o paradoxo da questão que ele efetivamente quer atingir,

\footnotetext{
${ }^{9}$ Cf., respectivamente, Górgias, 463 e Fedro 276 a.

${ }^{10}$ Cf. Fédon, $81 \mathrm{~d}$.

${ }^{11}$ Cf. República, 516a.

12 Sofista, 240a.

${ }^{13}$ Ibid., 240b.
} 
qual seja: supondo-se que é verdadeiro somente aquilo que realmente é, ou existe, chegase à conclusão de que aquilo que é somente semelhante não existe. No entanto - enfatiza o Estrangeiro -, devemos admitir que o que é somente semelhante a outro objeto também existe. Diante deste argumento, Teeteto não tem outra saída senão a de ajuntar esta

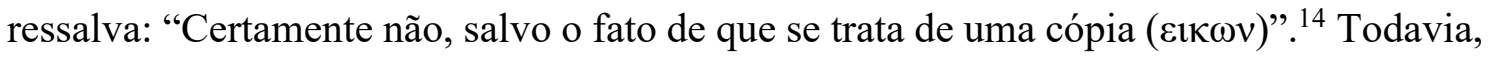
o Estrangeiro não larga a presa e insiste sobre a questão quanto a saber se aquilo que dizemos ser realmente uma cópia não existe também na realidade, ou enquanto realidade. Resta, pois, a Teeteto somente reconhecer que, de maneira insólita e paradoxal ( $\alpha \tau \mathrm{o} \pi \mathrm{ov})$, deve haver um certo entrelaçamento $(\sigma \nu \mu \pi \lambda \mathrm{o} \eta)$ ligando o ser ao não-ser e, poderíamos ajuntar, o paradigma à imagem, o modelo à cópia, aquilo que realmente é àquilo que lhe é semelhante. ${ }^{15}$

É nisto, com efeito, que consiste o paradoxo fundamental do ser $e$ do não-ser, da potência $e$ do ato, daquilo que ainda não é, mas está para ser, ou está vindo a ser. Tratase, em outros termos, da ponte, da passagem, da porta, da letra ou, para empregar a minha expressão favorita, do paradoxo do entre-dois. Portanto, a ambiguidade inerente à imagem reside em que, de um lado, ela não é o modelo, por mais perfeita que ela seja; de outro lado, porém, conquanto imperfeita, ela ainda guarda algo do modelo ou, para usar um conceito típico de Platão e da tradição cristã dos primeiros séculos - Paulo Apóstolo, Clemente de Alexandria, Orígenes, Atanásio, Hilário de Poitiers, Gregório de Nissa, Agostinho de Hipona - ela participa do modelo do qual ela exprime a semelhança. Mas o que Agostinho entende pelo conceito de participação? E participação a quê?

\section{A participação ao Ser, ao Uno e, portanto, ao Belo}

No Livro I das Enéadas, ao falar da aspiração que tem toda alma a subir em direção ao Bem - considerado como a causa da vida, da inteligência e do ser - Plotino assevera que o Belo "é, de fato, a verdadeira e primeira beleza que torna belos e amáveis os seus amantes". ${ }^{16}$ É que o Belo, o Bem e Deus se equivalem na concepção fundamental do filósofo, na medida em que são o princípio e a causa de todos os seres ou, numa palavra, são o Ser enquanto Ser. Com efeito, é do Belo em si que dimana toda beleza e toda tendência a ser como ele; é o Belo enquanto Belo que provê de beleza todas as coisas, das

\footnotetext{
14 Ibid.

${ }^{15}$ Cf. ibid., 240c.

${ }^{16}$ PLOTINO. Enneadi. Milano: Bompiani, 2004, I, 6,7.
} 
mais baixas às mais elevadas. Melhor ainda: "Todas as outras belezas são adquiridas, misturadas, não primitivas, porquanto dele provêm". ${ }^{17}$

O próprio Agostinho, ao se referir explicitamente a Plotino na Cidade de Deus, lembra que o filósofo admite sem hesitação que a beleza expressa nas plantas e nas flores deriva do sumo Deus, ao qual pertence, de modo inefavelmente inteligível, a beleza que ele faz chegar até às coisas mais ínfimas da terra. Ainda segundo Agostinho, Plotino declara que todas as coisas desprezíveis e extremamente precárias só têm graus convenientes das próprias formas porque a recebem do Ser, no qual se encontra a forma inteligível que jamais vem a ser e que, portanto, possui em ato a totalidade do Ser. ${ }^{18}$ Ocorre, porém, que uma das marcas originais em Agostinho - como, de resto, em todo pensador cristão - é a doutrina da criação. Certo, esta doutrina não era de todo ausente do pensamento grego, haja vista a formação, ou a geração, do mundo por obra do Demiurgo. Efetivamente, segundo Platão, o mundo foi gerado $(\gamma \varepsilon \gamma o v \varepsilon v)^{19}$, todavia, tudo aquilo que é gerado é de natureza corpórea. Consequentemente, a formação do corpo do universo se deu a partir dos quatro elementos já existentes, que foram proporcionalmente distribuídos pelo artífice do universo. ${ }^{20}$ Ademais, esta geração, ou formação, só foi possível graças a um modelo imutável, e idêntico a si mesmo, sobre o qual o Demiurgo fixou o olhar e dele reproduziu a beleza, a proporção e a harmonia. Assim gerado, conclui Platão, é

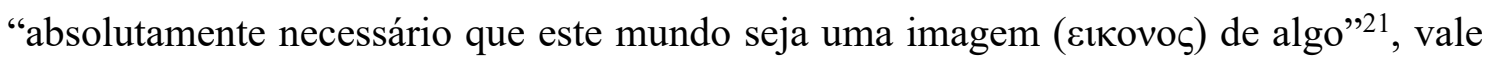
dizer, de um paradigma, ou de um modelo, do qual ele participa, justamente por ser dele a imagem, o reflexo ou a manifestação.

Ora, é no pensamento cristão que irá sobressair a doutrina da criação ex nihilo, a qual, tendo sido elaborada principalmente por Irineu de Lião (c. 130 - c. 202), remonta até ao exegeta judeu, Filão de Alexandria (25/20 a. C. - 50 d. C). Filão, que tentou realizar uma síntese entre a filosofia de Platão e as Escrituras, considerava as Ideias como sendo pensamentos de Deus e, portanto, não como entidades transcendentes a Deus, o qual, diz Filão, "criando todas as coisas, não somente as deu à luz, mas antes criou tudo aquilo que primeiramente não existia: ele não é, pois, somente um construtor, mas um verdadeiro fundador $(\kappa \tau \imath \sigma \tau \eta \varsigma) " .22$

\footnotetext{
${ }^{17}$ Ibid.

${ }^{18}$ Cf. AGOSTINHO DE HIPONA. La città di Dio. Roma: Città Nuova, 2000, X, 14. Com relação a Plotino, veja: Enneadi, op. cit., III, 2, 13.

${ }^{19}$ Cf. PLATÃO. Timeu, 28 b.

${ }^{20} \mathrm{Cf}$. ibid., 31 bss.

${ }^{21}$ Ibid., $29 \mathrm{~b}$.

${ }^{22}$ FILÃ̃ DE ALEXANDRIA. De somniis I-II. Paris: Éditions du Cerf, 1962, I, 13.
} 
Estas intuições de Filão de Alexandria - juntamente com a doutrina platônica da geração do mundo como imagem do modelo que o Demiurgo plasmou - tiveram uma influência preponderante no início do pensamento cristão no que diz respeito à questão da criação. Assim, para Agostinho, ela se desenrola segundo o modelo das ideias divinas naquilo que ela tem de ordem, de forma, de proporção e fecundidade. Tudo isto já é a expressão da semelhança ou, mais exatamente, do vínculo essencial que liga este mundo a Deus, pois, sem ele, o próprio universo deixaria de ser inteligível, de se conservar, ou mesmo de existir. Para ilustrar esta ideia, Agostinho se serve do relato de Exodo 3, 14, segundo o qual Iahweh ordenara a Moisés: "Eu sou aquele que é”. Ora, "Aquele que é”, justamente por se revelar como o Ser por excelência, ou como a suprema essência, não nasce, não perece, não se transforma e, portanto, não vem a ser. Ademais, ele é uno enquanto ser absoluto. Sendo, portanto, uno e absoluto, ele pôde dar às coisas criadas participarem de seu próprio ser, não no sumo grau - o que seria contraditório - mas em graus diferentes: a uns mais e a outros menos, e isto de acordo com a função assinalada a cada ser no ato da criação. Consequentemente, pondera Étienne Gilson: "A desigualdade e a disposição hierárquica das essências se funda sobre a desigualdade das participações possíveis ao Ser, do qual cada uma é representada por uma das ideias de Deus". ${ }^{23}$

As ideias de Deus constituem um dos conceitos fundamentais do medioplatonismo, movimento de caráter difuso predominante entre o primeiro século e o início do terceiro século da era imperial. Tratava-se, dentre outras características, de uma tentativa de mediar as intuições de Aristóteles com aquelas de Platão. Neste sentido, havia, segundo Albino (século II), os inteligíveis primeiros, que são as Ideias na mente de Deus, e os inteligíveis segundos, que são as formas imanentes às coisas. Para os medioplatônicos cristãos, as ideias são, decerto, paradigmas ou modelos a partir dos quais as coisas podem atualizar-se ou não. Mas, diferentemente de Platão, estas Ideias - que se encontram na mente de Deus - foram criadas pelo próprio Deus. Um eco dessas influências, vamos encontrá-lo também no Comentário ao Evangelho de João. Aqui, já na Homilia 1, Agostinho se serve da metáfora do armário que, antes de ser fabricado, já se acha, como ideia, na mente do artesão que o realizará. Se o artesão já não tivesse a forma do armário na mente - interroga-se Agostinho - como poderia ele então confeccioná-lo? Mas uma coisa é o armário tal como ele se encontra sob a forma de ideia na mente do artesão e outra coisa é o armário atualizado. Aquele - sublinha o teólogo -, nós não podemos vê-

${ }^{23}$ GILSON, Étienne. Introduction à l'étude de Saint Augustin. Paris: Vrin, 2003, p. 275. 
lo com os olhos do corpo, enquanto que o armário atualizado se torna visível, tangível, palpável. Todavia, ele continua a existir como ideia, ou como forma, na mente do artesão. Assim também, conclui o teólogo, ocorre com a sabedoria de Deus, por meio da qual todas as coisas foram criadas. Como mente criadora, ela já possuía todas essas coisas antes mesmo que elas começassem a existir de maneira visível. De sorte que - pondera o autor das Confissões - a sabedoria, ao criar a terra, o céu, o sol, a lua e as demais coisas corpóreas, visíveis, ela não fez senão que se manifestasse aquilo que já existia, como ideia, na mente de Deus. ${ }^{24}$

Daí poder-se deduzir que, para Agostinho, é em Deus que se encontra a raiz da unidade, do ser e, consequentemente, do belo. Com efeito, ao comentar a concepção de Hilário de Poitiers sobre as propriedades das pessoas na Trindade, segundo a qual a eternidade está no Pai, a forma na Imagem e a fruição no Dom, Agostinho conclui que o Pai não tem um Pai do qual proceda, enquanto que o Filho recebe do Pai a sua existência e, por conseguinte, a sua co-eternidade. Ora, se a imagem reproduz com toda a fidelidade a realidade da qual ela é a imagem, não se pode senão inferir que ela se identifica com a realidade, e não a realidade com a imagem. Neste sentido, o teólogo é enfático ao afirmar: "Nesta imagem, ele (o Pai) faz sobressair a forma (species) por causa, creio eu, da beleza que surge desta perfeita proporção". ${ }^{25} \mathrm{E}$, melhor ainda, a beleza surge "desta suma igualdade, desta suprema semelhança, sem nenhuma diferença, nenhuma desproporção nem dessemelhança, mas em tudo similar ao objeto do qual ela é a imagem". ${ }^{26}$ Mas como então falar de uma suprema semelhança da imagem - sem nenhuma diferença - com relação ao objeto do qual ela é a imagem? De fato, conforme a conclusão a que chegamos na seção anterior, a ambiguidade fundamental que caracteriza a imagem consiste em que, de um lado, por mais perfeita que ela seja, ela não é o modelo, de outro lado, porém, mesmo sendo imperfeita e incompleta, ela ainda conserva traços, indícios e, portanto, semelhanças do modelo que ela reproduz, ou tenta reproduzir. A este propósito, convém lembrar que a inferioridade da imagem vis-à-vis do modelo foi uma das características do medioplatonismo e foi ela que ensejou a suspeição e acusação de subordinacionismo contra Orígenes (c. 185 - c. 253) que, no entanto, enfatizava a geração eterna do Logos. ${ }^{27}$

\footnotetext{
${ }^{24}$ Cf. AGOSTINHO DE HIPONA. Commento al Vangelo di Giovanni. Roma: Città Nuova, 2005, Omelia $1,17$.

${ }^{25}$ AGOSTINHO DE HIPONA. La Trinità. Roma: Città Nuova, 1998, VI, 10, 11.

${ }^{26}$ Ibid.

${ }^{27}$ Sobre a questão da imagem em Orígenes, veja: ORÍGENES. On First Principles. New York: Harper Torchbooks, 1966, Book I, Chapter II.
} 
Todavia, Agostinho, parece estar cônscio desta problemática, pois, ao final do Livro VII da Trindade, ele evoca a distinção que costumavam fazer alguns Padres da Igreja entre a Imagem como Filho de Deus e ad imagine, que diz respeito ao homem enquanto criatura. Efetivamente, no que tange ao homem (ad imagem), ela jamais será igual ao modelo, mas dele se avizinha somente através de certa semelhança. Segundo Agostinho, o homem não pode aproximar-se de Deus superando distâncias espaciais, mas fazendo-se a ele semelhante; inversamente, porém, pode o homem dele afastar-se pela dessemelhança. Agostinho tenta solucionar a questão da imagem aduzindo passagens das Escrituras e, mais precisamente, a Primeira e a Segunda Carta de Paulo aos Coríntios e a Carta aos Colossenses. Mas aquilo que ele realmente tenciona ressaltar é o papel da imagem do homem vis-à-vis da Trindade, vale dizer, do Pai, do Filho e do Espírito Santo nas suas relações e no seu pertencimento mútuo, essencial, pericorético. Donde a frase lapidar com a qual o teólogo encima todo o seu raciocínio: "Deus é a Trindade" (Deus autem Trinitas). ${ }^{28}$ Sendo, pois, Deus a Trindade, o homem - enquanto criatura feita à sua imagem e como a sua semelhança - participa dessa Trindade.

Na verdade, na perspectiva do autor da Cidade de Deus, todas as criaturas, no que tange à bondade e à beleza, participam, de uma maneira ou de outra, da ação do Criador. Conforme pudemos deduzir ao longo destas reflexões, a doutrina da participação tem uma dupla tradição: a das Escrituras - "Façamos o homem à nossa imagem, como nossa semelhança" (Gn 1,26) - e a da filosofia de Platão. Com efeito, no Fédon, o filósofo afirma: "Nada torna bela uma coisa senão a presença $(\pi \alpha \rho 0 v \sigma 1 \alpha)$ ou a participação

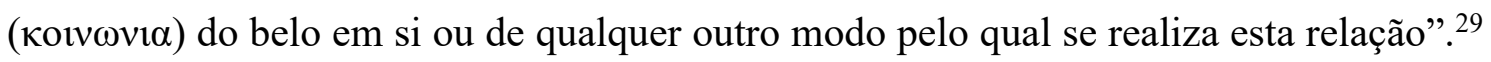
No Parmênides, Platão concebe a participação como imitação, na medida em que: "Essas formas $(\varepsilon 1 \delta \eta)$ subsistem na natureza como modelos $(\pi \alpha \rho \alpha \delta \varepsilon 1 \gamma \mu \alpha \tau \alpha)$, enquanto que as outras coisas se assemelham a elas e são imitações; e a famosa participação ( $\mu \varepsilon \theta \varepsilon \xi 1 \varsigma)$ às formas que interessa às outras coisas não se dá senão pelo fato de que estas últimas são constituídas à imitação daquelas". ${ }^{30} \mathrm{Na}$ concepção platônica e neoplatônica, os seres tendem, portanto, a imitarem o Ser ou os paradigmas que o constituem essencialmente.

Ora, no que diz respeito à obra de arte, a imagem é aquilo que aspira a aproximar-se o máximo possível de seu modelo. Ela tende, pois, a realizar uma correspondência, uma simetria, uma semelhança e, possivelmente, uma igualdade com o modelo que ela tenta

\footnotetext{
${ }^{28}$ AGOSTINHO DE HIPONA. La Trinità, op. cit., VII, 6, 12.

${ }^{29}$ PLATÃO. Fédon, 100d.

${ }^{30}$ PLATÃO. Parmênides 132d.
} 
reproduzir, embora ela permaneça como imagem. Efetivamente, se se pode falar de uma correspondência perfeita entre a imagem e o seu modelo, esta perfeição reside no poder que tem a imagem de reproduzir, no seu mais alto grau, a semelhança que existe entre ela e o seu modelo. Não obstante isso - repita-se -, a imagem continuaria sendo imagem e o modelo, modelo. No que tange mais especificamente à relação criatura-Criador, a semelhança consiste na capacidade que têm as coisas criadas de se aproximarem, ou de participarem, do Ser, do Uno e, consequentemente, do Belo. E elas serão tanto mais belas quanto mais harmoniosas, proporcionais e ordenadas forem as suas partes entre si. Neste sentido, ao comentar o último dia da criação - "Deus viu tudo o que tinha feito, e era muito bom" (Gn 1,31) -, Agostinho ajunta que, quando se trata da criação dos seres tomados individualmente, a Escritura simplesmente diz: "Deus viu que isso era bom". Quando, porém, se refere ao conjunto de todos os seres criados, não é suficiente simplesmente dizer "bom", mas urge ainda exclamar: "muito bom”. A sua conclusão consiste, portanto, no seguinte: se, consideradas individualmente, as obras de Deus são dignas de louvor em virtude de sua medida, de seu número e de sua ordem, quanto mais louváveis serão elas quando vistas na sua unidade, totalidade e universalidade! Efetivamente, acrescenta o teólogo: "Toda beleza que é composta de partes é mais digna de louvor no seu conjunto do que numa de suas partes tomada isoladamente". ${ }^{31}$ A título de ilustração, ele evoca a figura do corpo humano, cuja beleza pode ser expressa, por exemplo, nos olhos, na face, no nariz, na cabeça, nas mãos, nos pés, mas - pondera Agostinho -, todas essas partes contribuem para uma beleza ainda maior quando o corpo é contemplado, observado ou examinado na sua inteireza. Por conseguinte: "A força e o poder da integridade e unidade são tão grandes que muitas coisas boas são agradáveis somente quando se encontram unidas, formando assim um universo (universum)". ${ }^{32}$

Segundo Agostinho, a beleza derivada da unidade, cuja harmonia se observa na obra da criação, isto é, nos corpos, nos fenômenos naturais, nos seres animados, nos seres inanimados e, enfim, em todo o universo, se traduz também na obra de arte produzida pelo homem. Assim, onde quer que existam ordem, harmonia e proporção ou, em outros termos, onde quer que exista unidade produzida pela semelhança, existirá também beleza. É o que o teólogo explica, de maneira resumida, condensada, sintética, no De musica: “A

31 AGOSTINHO DE HIPONA. On Genesis: Two Books on Genesis against the Manichees and On the Literal Interpretation of Genesis: An Unfinished Book. Washington, D.C.: The Catholic University of America Press, 1991, p. 80.

${ }^{32}$ Ibid. 
harmonia (numerus) começa pela unidade, ela tira a sua beleza da igualdade (aequalitas) e da simetria (similitudo); a ordem é delas a união". ${ }^{33}$

\section{A ordem, a proporção e o número}

Essa concepção é típica da tradição platônico-aristotélica. Com efeito, para Aristóteles, o belo é constituído pela ordem, pela simetria e por uma grandeza apta a ser abraçada por um simples olhar. Assim, ao analisar a narrativa ou o enredo na tragédia, o Estagirita afirma que, para ser belo, todo ser - seja ele um animal ou qualquer outro ser composto de partes - deve não somente ter suas partes proporcionalmente ordenadas, mas também manifestar uma grandeza que não vá além nem aquém do campo de visão daquele que o observa. É que, diz o filósofo, o belo reside na grandeza e na disposição ordenada de suas partes. ${ }^{34}$ Esta doutrina, que já se encontrava na República de Platão, foi retomada pelos estoicos e reelaborada por Cícero nestes termos:

Assim como existe no corpo uma equilibrada conformação dos membros unida a um colorido de aspecto agradável - e a isto se dá o nome de beleza -, assim também na alma se denomina beleza o equilíbrio e a coerência das opiniões e dos juízos unidos a uma espécie de firmeza e estabilidade, que é consequência da virtude ou que encerra a própria essência da virtude. ${ }^{35}$

Essa visão do belo como proporção, unidade e equilíbrio teve repercussão não somente sobre Agostinho, mas também sobre o pensamento medieval - inclusive aquele de Tomás de Aquino - e igualmente sobre a arte renascentista, cujo ideal de simetria, harmonia e proporcionalidade remonta, como se sabe, ao período clássico grego. Em Agostinho e, mais especificamente, na Verdadeira religião (389-391), o corpo é descrito como tendo uma certa harmonia, ou uma certa concordância, nas suas partes. Sem esta harmonia, ele não poderia nem mesmo ser considerado corpo, porquanto ele é obra d'Aquele que é o princípio de toda concórdia e de toda proporção. Sem esta proporção e este equilíbrio na forma, ele nada seria. Consequentemente, o corpo possui um certo aspecto de beleza, pois, segundo o teólogo, ele foi criado por Deus. Efetivamente: "Se alguém se perguntar quem constituiu os corpos, que procure entre todos os seres aquele que possui a beleza ideal, pois toda beleza (species) procede dele". ${ }^{36}$ Neste mesmo escrito, e nesta mesma

\footnotetext{
${ }^{33}$ AGOSTINHO DE HIPONA. La musique. In Dialogues philosophiques, VII. Paris: Desclée de Brouwer, 1947, Livre VI, XVII, 56.

${ }^{34}$ Cf. ARISTÓLES. Poetica. Milano: Rusconi, 1995, 7, 1450 b-1451a.

${ }^{35}$ CÍCERO. Tuscolane. Milano: BUR, 2004, Libro Quarto, XIII, 31.

${ }^{36}$ AGOSTINHO DE HIPONA. La vraie religion. In Dialogues philosophiques, VIII. Paris: Desclée de Brouwer, 1951, XI, 21.
} 
linha de reflexão, ele desloca o acento para a própria obra de arte, cujo deleite reside na harmonia (convenientia) que, somente ela, assegura a integridade e a beleza. De fato, sublinha o autor das Confissões, a harmonia quer a igualdade e a unidade realizadas pela semelhança dos elementos simétricos, ou pela proporção daqueles que são dissemelhantes. ${ }^{37}$

A manifestação dessa beleza se verifica primeiramente na ordem dos corpos naturais, no sentido em que a harmonia e a proporção se revelam, antes de tudo, em casos particulares de semelhança. É o que se observa, por exemplo, nas árvores de uma mesma espécie que germinam, crescem, florescem e produzem frutos de acordo com uma certa ordem e uma certa regularidade. De igual modo, os animais de uma mesma espécie formam uma unidade através da semelhança que existe entre os diferentes indivíduos que a compõem a partir de seus respectivos traços. O mesmo se pode também dizer com relação à esfera do psíquico ou do espiritual. Assim, uma alma é uma alma na medida em que ela manifesta uma certa constância consigo própria, vale dizer, uma regularidade no cumprimento de suas ações, na repetição de seus atos e no desempenho de suas funções intelectuais, éticas e espirituais. De resto, para Agostinho, todo ser vivo é constituído de partes simétricas, proporcionais, cuja correspondência, ou homologia, lhe assegura a unidade e a beleza. Enfim, o próprio universo, enquanto kósmos, só é belo na medida em que é feito de seres dos quais cada um é aquilo que é em virtude da semelhança que reina entre as suas partes. Todos são, portanto, semelhantes entre si graças à sua comum relação com a unidade criadora que, segundo Agostinho, ultrapassa todo raciocínio humano. É o que ele afirma no seu Comentário literal ao Gênesis, ao enfatizar: “A grandeza do poder que tem a semelhança com Deus, através da qual todos os seres foram feitos, consiste em impor unidade às coisas, e este poder ultrapassa grandemente o pensamento humano". ${ }^{38}$ Certo, ao observar a natureza e imaginando-a como um todo, nós podemos obter alguma ideia desse poder ao considerarmos a unidade que reina entre as suas partes. Não podemos, porém, deduzir, demonstrar e, menos ainda, provar o princípio a partir do qual se desdobra esta unidade, que é responsável pela beleza do cosmos. Na perspectiva de Agostinho, tudo isso se reporta, em última análise, a Deus, o que equivale a dizer que seria vão todo empreendimento tendente a compreender, ou a definir, aquilo que por natureza transcende, escapa e se subtrai a toda argumentação ou explicação racional.

\footnotetext{
${ }^{37}$ Cf. ibid., XXX, 55.

${ }^{38}$ On Genesis: Two Books on Genesis against the Manichees and On the Literal Interpretation of Genesis: An Unfinished Book, op. cit., p. 185.
} 
Curioso, no entanto, é notar que a harmonia e a beleza que formam essa unidade podem, a qualquer momento, ser quebradas, rompidas, transgredidas. Pense-se, por exemplo, nas catástrofes naturais - um terremoto, um maremoto, um incêndio - e também nas transgressões em que incorre o próprio ser humano na esfera da moral e da religião. Todavia, a ambiguidade fundamental dessas rupturas reside em que, apesar delas, a natureza e as relações humanas continuam, como um todo, a desenrolar-se e a repetir-se regularmente. Uma repetição que se desdobra na identidade, na semelhança e, ao mesmo tempo, na diferença. Esta visão remonta à filosofia estoica, que vê o bem como inseparável do mal. Melhor ainda, o mal termina, paradoxalmente, por revelar-se como a condição mesma para que o bem exista.

\section{Conclusão}

Efetivamente, uma das características principais da ética do estoicismo primitivo, que tanta influência exercera sobre o pensamento cristão dos primeiros séculos - e sobre Agostinho em particular - consiste justamente no paradoxo do apesar de. Nesta ambiguidade fundamental, o pequeno concorre para o grande, o desarmônico para o harmonioso, o desgracioso para o belo, o mal para o bem. Vemos este paradoxo exprimirse com toda a sua força no Livro VII das Confissões, onde o teólogo afirma:

Em ti não existe absolutamente o mal, e não somente em ti, mas também em toda a tua criação, fora da qual nada há que possa irromper e corromper a ordem que nela impuseste. Dentre, pois, as partes da criação, existem algumas que, por não estarem de acordo com outras, são consideradas más, enquanto que com outras elas se harmonizam e, por isso, são boas tomadas conjuntamente e, portanto, boas em si mesmas. ${ }^{39}$

No que diz respeito às relações intersubjetivas, o teólogo considera que os costumes produzem amizade e concórdia entre os seres humanos. Todavia, em cada indivíduo tomado particularmente, as ações e as virtudes - sem as quais é impossível conceber a constância e a regularidade - podem também ser a marca de uma vida feliz. Não obstante isso, ou talvez por isso mesmo, pondera Agostinho, pode-se deduzir que todas essas coisas são semelhantes, mas não são a semelhança enquanto tal. Com efeito, para o autor das Confissões, o universo é constituído de coisas semelhantes entre si, mas as coisas individuais só são aquilo que são na medida em que todas preenchem - de acordo com os graus que lhes são correspondentes - o universo que Deus criou e governa continuamente.

\footnotetext{
${ }^{39}$ AGOSTINHO DE HIPONA. Le Confessioni, op. cit., VII, 13, 19.
} 
Isto quer dizer que, em Agostinho, a beleza na natureza, a beleza no universo e na obra de arte não podem ser pensadas sem o Ser e, portanto, sem a verdade. De fato, o teólogo vê em todos os seres, inclusive nos corpos, na matéria e no mundo da sensibilidade, uma espécie de verdade e de falsidade ou, para dizê-lo de outro modo, existem graus de verdade e de falsidade na escala das coisas que compõem o cosmos. Donde poder-se inferir que os seres são em virtude de uma certa verdade que lhes é inerente, ou que lhes é essencial. Donde também a fórmula elíptica a que inevitavelmente se devia chegar: o que é verdadeiro é verdadeiro na medida, e somente na medida, em que é; inversamente, o que é, é somente na medida em que é verdadeiro. Neste sentido, o Verbo aparece como a forma de tudo aquilo que é e, portanto, como a semelhança suprema do Pai. Juntamente com o Pai e o Espírito, o Verbo confere a todas as coisas o seu ser, que se traduz pela unidade, a verdade e a beleza.

Mas se as coisas se apresentam assim com relação à ordem do ser, nada existe no universo que não encontre em Deus a sua razão última de existir. Todavia, esta obra de Deus, que não se explica senão pelo próprio Deus, torna-se por sua vez o meio pelo qual nós podemos, de certo modo e até certa medida, conhecê-lo. A conclusão, pois, a que é levado Agostinho não poderia ser outra senão esta: se o universo não é senão uma imagem de Deus, esta imagem deve poder permitir ao homem tornar-se, de alguma forma e até certo ponto, a natureza, ou a semelhança, do seu autor.

\section{Referências}

AGOSTINHO DE HIPONA. La città di Dio. Roma: Città Nuova, 2000.

. Commento al Vangelo di Giovanni. Roma: Città Nuova, 2005.

. Le Confessioni. Torino: Einaudi, 2002.

. La natura del bene. Milano: Rusconi, 1995.

1947.

. La musique. In Dialogues philosophiques, VII. Paris: Desclée de Brouwer, . La Trinità. Roma: Città Nuova, 1998.

. La vraie religion. In Dialogues philosophiques, VIII. Paris: Desclée de Brouwer, 1951. 
. On Genesis: Two Books on Genesis against the Manichees and On the Literal Interpretation of Genesis: An Unfinished Book. Washington, D.C.: The Catholic University of America Press, 1991.

ARISTÓTELES. Poetica. Milano: Rusconi, 1995.

BÍBLIDA (A) DE JERUSALÉM. São Paulo: Paulus, 1985.

CÍCERO. Tuscolane. Milano: BUR, 2004.

FILÃO DE ALEXANDRIA. De somniis I-II. Paris: Éditions du Cerf, 1962.

GILSON, Étienne. Introduction à l'étude de Saint Augustin. Paris: Vrin, 2003.

ORÍGENES. On First Principles. New York: Harper Torchbooks, 1966, Book I, Ch. II.

PLATÃO. Plato in Twelve Volumes. Cambridge: Harvard University Press, 1977.

PLOTINO. Enneadi. Milano: Bompiani, 2004. 